\section{Social Economy as Possible Solution for Social Inclusion and Combating Poverty in Romania}

\section{Geta MITREA ${ }^{1}$}

${ }^{1}$ Lecturer PhD, "Stefan cel Mare" of Suceava, Suceava, Romania, geta.mitrea@usv.ro
Abstract: The sector of social economy grew and gained its own place in the actual social and economic activity at local, regional and national level in Romania. Even though until 2015 there was no clear legislative regulation social economy entities were created and contributed to the community development and job offers for vulnerable persons. This paper is focusing on a case study of best practices in social economy of entities from Romania.

The main goal was to present the financial opportunities existing after we became a member of the European Union, social indicators targeted and achieved by these projects. Finally, to present two best practices of social economy entities created and acting in Romania. We will also focus on its collaborative economy for developing the social and economic communities where they were acting. Namely, Non-Governmental Professional Association of Social Work (ASSOC) from Baia Mare, Maramures and Alături de Voi Romania (ADV Romania) from Iasi.

Keywords: social economy; social inclusion; poverty; european funds; social entities.

How to cite: Mitrea, G. (2021). Social Economy as Possible Solution for Social Inclusion and Combating Poverty in Romania. Logos Universality Mentality Education Novelty: Economics and Administrative Sciences, 6(1), 34-44. https://doi.org/10.18662/lumeneas/6.1/27 


\section{Introduction}

During the last years the sector of social economy stared to clearly delimitate and gain its own place in the actual social and economic activity at local, regional and national level in Romania. At global level (Stukalo \& Simakhova, 2018) this domain has already a stable background and even a tradition in developed countries from Europe, - such as Finland, Denmark, Switzerland, Spain, Italy, Sweden, - and from United States of America. One of the main reasons why the social economy stayed at a hibernated level in our country was because of the communism period. Their doctrine regime focused on total "human equality and fraternity" (Tismăneanu, 2006) and by means any kind of social services or actions were not recognized, including social economy.

Once with the collapse of Union of Soviet Socialist Republics (URSS), in the '90s, social economy in Romania started, step-by-step, to develop and play an even more important place in the stage of social end economically growth and human resources management and sustainability (Roldán \& Cabrales, 2021). There was a period of uncertainty and no clear legal stipulations for this domain. Experts from that time created NonGovernmental Organizations (NGOs) for offering social services and social benefits for vulnerable people, helping persons in need and reduce poverty with the help of cooperative helping groups (Meira, 2019). In parallel, international organizations from different parts of the world initiated local branches and implemented social actions for people from Romania to contribute at social inclusion of vulnerable categories existing in that period.

Because of its novelty in Romania when we tried to find a clear definition in the online version of the Explanatory Dictionary of the Romanian Language (n.d.), this term was scored with zero results, unfortunately. I asked myself why is the reason for not existing a clear definition of this term in such a relevant book? First, I believed that the only involvement of the work "economic" takes the person's mind at the element of "economy, profit, money, investment". I totally agree that people's thoughts are correct but, unfortunately we forget the first word from the expression -"social". At a slight sight we do not give a proper meaning of the entire expression of "social economy" and we simply consider that is an "economy for social field". This interpretation is not wrong at all, but we forget the main purpose of it: the main beneficiaries are the vulnerable people, the persons who are in the evidence of local social services or who do not afford to take care of themselves. In this context, the "social economy is the main key for finding solutions for social inclusion. And with the contribution of different actors from public and private sector, even 
stakeholders collaborate (Laurisz, 2019) to pursue the main goal of its activity -"helping people in need, increasing social inclusion and contributing to economic growth for the region, country where it is implemented".

Because of its unclear definition or even legal regulations for over the years, a long period of time there was no national legislation for governing the domain of social economy. At national level in 2015 was issued the Law 219 of social economy that established the main rules and framework for the field of social economy in our country. This law, - mainly in the article 2, paragraph 1, - stipulates the meaning of the term "social economy" to be defined as "the set of activities organized independently of the public sector, whose purpose is to serve the general interest, the interests of a community and/or non-patrimonial personal interests, by increasing the degree of employment of persons belonging to the vulnerable group and/or the production and supply of goods, the provision of services and/or execution of works" (Romanian Parliament, 2015). The same law stipulates also the private involvement in this sector of organizations and mentions that their involvement has to be "voluntary and supportive, with a high degree of autonomy and responsibility, as well as the limited distribution of the profit to the associates" (Romanian Parliament, 2015). The main objective of this law is to put in the center the social inclusion of vulnerable people from our country by creating new jobs for them and contributing at the development of the communities.

Why did this law was issued in 2015 and not early? If there was a cleared legislation sooner than 2015 maybe the social economy domain was more developed in present; we had fewer vulnerable persons with stable jobs and contributing to social economy and rural development (Carrión et al., 2020)? Or, now we were able to innovate in social economy as similar developed countries from all around the world. We still do not have a proper answer to this question but we will try to find out in the next part of this paper.

\section{Methodology of the Study}

This paper is focusing on a case study of best practices in social economy of entities from Romania. The main goal of this article was to make a short presentation of the term "social economy", a short history of social economy form Romania, legislation background, the financial opportunities existing after we became a member of the European Union, social indicators targeted and achieved by these projects.

Finally, we want to present best practices of social economy entities created in Romania and its social actions for contributing at social and 
economic development of the communities where they were having their headquarters, namely: ASSOC and ADV Romania.

As main sources of information for this paper we used the existing laws, the official websites of the Ministry of Finance and Economy existing during the programming period of 2007-2013 and the Ministry of European Investment and Projects from the period 2014-2020, the official websites of ASSOC and ADV Romania, international articles regarding this issue. In the sense of financial support of social economy, it is necessary to present the funding opportunities existing for this domain and after that to pass at the next stage of presenting the best practices existing at national level and their visible local impact.

\section{Funding opportunities for social economy in the context of social inclusion}

Since 2007 when we became a member of European Union our country had the opportunity to access projects from non-reimbursement funds for developing the social economy domain. At the beginning, this opportunity was offered through the Sectoral Operational Program Human Resources Development 2007-2013 (SOP HRD) (Ministry of Finance and Economy, n.d.), priority axis 6 titled promoting social inclusion. As a main objective for this program during the period of 2007-2014 the authorities established that 830 entities of social economy must be founded. In the final Annual implementation report of the program (Ministry of European Funds, 2014) are presented the results obtained during the period of implementation. We are able to see that the base of the program for social economy started from the number of three entities in social economy already existing at that time in Romania. The final target was that by the end of 2014 in Romania should me founded almost 830 new entities of social economy. As we can see in table no. 1 below each year the number of social economy entities grew and step-by-step reached the target established by the program.

Table 1. Number of entities founded on social economy during 2007-2014 in Romania

\begin{tabular}{ccccc}
\hline Indicator & Accomplished & Target & Base & $\%$ \\
\hline $\begin{array}{c}\text { Number of entities on } \\
\text { social economy that has to }\end{array}$ & & & 3 & \\
be founded & & & & \\
2007 & 0 & - & & \\
2008 & 11 & 92 & $0,12 \%$ \\
2009 & 14 & 190 & $0,07 \%$ \\
\hline
\end{tabular}


Social Economy as Possible Solution for Social Inclusion and Combating... Geta MITREA

\begin{tabular}{cccc}
\hline 2010 & 73 & 310 & $0,24 \%$ \\
2011 & 144 & 450 & $0,32 \%$ \\
2012 & 261 & 605 & $0,43 \%$ \\
2013 & 346 & 770 & $0,45 \%$ \\
2014 & 346 & 830 & $0,42 \%$ \\
2015 & & 830 & \\
TOTAL & & 830 & \\
\hline
\end{tabular}

Source: Ministry of Finance and Economy (2014)

As we can notice from the above table we can see that each year accomplished number versus the target one are smaller. The year 2013 ranks the first because there was the highest percentage reached to the target objective $(0,45 \%)$. And the first three positions are occupied by the period of 2012-2014, at the end of the program fund. An explanation of this rank may be the fact that at the beginning of the program period the potential beneficiaries did not have enough information or the rules of this type of projects were not very clear for them. And, because of these reasons in the first year of the program there was not established target and no projects contracted. Also, another explication can be the fact that since the 2012 the Management Authority included as mandatory indicators for funded projects the programs indicators. For example, a beneficiary of a project on the priority axis would have to accomplish a minimum of social economy entities created in rural areas. In case this indicator was not included in the application form the project would not be considered as eligible for funding. In this way, step-by-step the target grew until reached 830 in 2014.

A linearity achievement it can easily be seen for each year and this helps us to understand that the social economy in our country grew gradually and settled a stable base for development involving social capital and civil participation (Mandrysz, 2020). In time, social economy contributed to its goal of social development for vulnerable persons and contributed at the creation of better relationships between the social economy, social welfare, and social innovation (Shin, 2016).

Another important indicator established by the SOP HRD was referring to the "number of participants in programs qualification/requalification for vulnerable groups, from which: roma people, people with disabled, young people who leave the state system protection (residential centers)" (Ministry of European Funds, 2014). Even though the target number was a high one, meaning that a total of 240.900 of persons of the above vulnerable categories were targeted to participate at different kinds of qualification/requalification programs. At the end of the 
program, in 2014 only a total number of 51.069 persons participated to such activities. Only a $0,21 \%$ of the indicators were reached, as can be seen in table 2 below.

Table 2. Ration of target and accomplished indicators established by SOP HRD during 2007-2014

\begin{tabular}{lccc}
\hline \multicolumn{1}{c}{ Indicator } & Accomplished & Target & $\begin{array}{c}\% \text { accom- } \\
\text { plished }\end{array}$ \\
\hline $\begin{array}{l}\text { Number of participants in pro- } \\
\text { grams qualifica- } \\
\text { tion/requalification for vulnera- } \\
\text { ble groups }\end{array}$ & 51.069 & 240.900 & $0,21 \%$ \\
$\begin{array}{l}\text { Number of dependent persons } \\
\text { supported }\end{array}$ & 8.814 & 40.000 & $0,22 \%$ \\
$\begin{array}{l}\text { Number of participants at train- } \\
\text { ing programs addressed to spe- } \\
\text { cialists in the social inclusion } \\
\text { domain }\end{array}$ & 16.476 & 10.000 & $1,64 \%$ \\
$\begin{array}{l}\text { Number of transnational initia- } \\
\text { tives and partnerships supported }\end{array}$ & 9 & 120 & $0,075 \%$ \\
$\begin{array}{l}\text { Number of jobs created by enti- } \\
\text { ties of social economy }\end{array}$ & 12.377 & 5.000 & $2,47 \%$ \\
\hline
\end{tabular}

Source: Ministry of Finance and Economy (2014)

We may state the fact that the SOP HRD reached its purpose regarding the social economy domain. Clearly, as it can be seen, the funds addressed this issue reached its proposed goal and we can sustain the fact that our membership in European Union contributed to the development (Carrión et al., 2020) of social economy in our country.

Even though the SOP HRD program's statistics reveal that an important step for social economic growth happened, the social economy was considered that it did not reach to its fully potential (Lee \& Jung, 2018). In this sense, after the SOP HRD ended its period another program continued to provide the opportunity for the social economy domain to expand and keep developing. This program is titled The Human Capital Operational Program 2014-2020 (POCU) (Managing Authority for the Human Capital Operational, 2020) and one of its main objectives is to keep 
developing the social economy potential and to "strengthen the capacity of social economy entities to function in a sustainable way for the social and labor market integration of vulnerable groups" (Managing Authority for the Human Capital Operational, 2020). In the Approved version of the Human Capital Operational Program it is also stated the fact that this period of fund program came as a solution. Especially, because until now the social economy is still "poorly developed, but with potential for job creation, implementation of social inclusion measures" (Managing Authority for the Human Capital Operational, 2020).

At the POCU program the priority axis addressing the social economy entities correlated with actions of social inclusion of vulnerable persons, combating poverty in disadvantaged communities, job development, promoting a healthy life style and environmental issues for sustainable development. All these from above contribute to a local and national innovation cooperation between public-private sector in social economy (del Carmen Muñoz Medraño et al., 2018). If at SOP HRD was the priority axis 6 , here at the next program period, POCU, there is the 4 priority axis where beneficiary can apply projects for funds.

For a clear image of how social economy can contribute to local development we will present next two best cases examples of entities acting in social economy field and its positive impact over the community.

\section{Romanian entities in social economy - best practices examples for combating poverty}

We choose to present two important and active NGOs in the field on social economy in two different parts of the country, namely: NonGovernmental Professional Association of Social Work (ASSOC) from Baia Mare, Maramures and Alături de Voi Romania (ADV Romania) from Iasi. Both of them are playing an important role in the social economy and jobs creation for vulnerable persons, helping to develop de communities where have the headquarter and even expended in other cities from Romania.

ASSOC was founded in 1995 as a NGO for offering social services for vulnerable persons as it is stated on their official website. Until present it has more than 22 years of activity and meanwhile "has created branches in cities such as: Bucharest, Arad, Suceava, Râmnicu Vâlcea" (ASSOC - NonGovernamental Profesional Asociation of Social Work, n.d.). This NGO also accessed projects from different funding sources among witch we find the SOP HRD 2007-2014 program. On their website they state that during 2013-2015 implemented 16 projects funder on the SOP HRD on priority 
axis 6.1. Development of the social economy. As final results of these projects the ASSOC "have ensured the establishment of 72 social economy structures at national level, structures that operate in areas such as: catering, archiving, meditations, cleaning, used food oil collection, home care, special transport, nature maintenance, accounting, marketing, residential center for the elderly, dental services, etc" (ASSOC, n.d.).

On their website we can easily navigate and access all the social economy structures created. For example, there is the social economy section for catering restaurant in cities like: Baia Mare, Maramureş - social restaurant; Târgu Neamț - Association "Saint Teodora" social enterprise; village Turt, Satu Mare - "Cart with goodies" Association; Arad - Catering Vinga; Sighetul Armatei, Maramureş - "Kiss Pipa Restaurant "; village Recea, Maramureş- " Bakery the bread of life" - social enterprise; Bucharest - social restaurant catering.

The extension of its social economy activities is very well received by the communities where they are placed and they answer to an already existing need also to the job creation for vulnerable people from those communities.

ADV Romania was founded in 2002 by Holt International Children's Service USA according to their official website. During their activity they founded "3 social businesses, being declared the 2016 Social Entrepreneur of the Year within the international competition EYEntrepreneur Of The Year" ("Alături de Voi" Romania (ADV), n.d.). Also in their activity they created "seven products for an integrated approach in the field of social economy" (ADV, n.d.).

ADV actively acts in the areas where they have the headquarters and also are involved in "training courses for entrepreneurs and social economy managers, study visits, national fairs and ensures counseling and coaching for the development of social enterprises" (ADV, n.d.). ADV also is a promoter of social economy in neighboring countries, namely Republic Moldova and Ukraine. In these countries they are implementing a large number of projects in partnership with homologs of them.

ADV created UtilDeco.ro ${ }^{1}$, JobDirect.ro ${ }^{2}$, wise.travel, Youth Club, ADV Academy. All of these are authorized protected unity, social enterprise and all the profit is reinvested in the community and creates new jobs for vulnerable people. Jobdirect.ro is the first platform from Romania where

\footnotetext{
${ }^{1}$ https://www.utildeco.ro/

${ }^{2}$ www.jobdirect.ro
} 
persons with disabilities may find proper jobs answering their needs. Here vulnerable people can create an account and apply for jobs offers of different organizations already enrolled on the platform.

Until present ADV Romania implemented 81 projects, had 180.000 beneficiary and contributed to the community investment with 30 million EUR. The global goal of sustainable development for ADV Romania can be seen in Figure 1 bellow.

THE CLOBAL COALS FOR SUSTAINABLE DEVELOPMENT

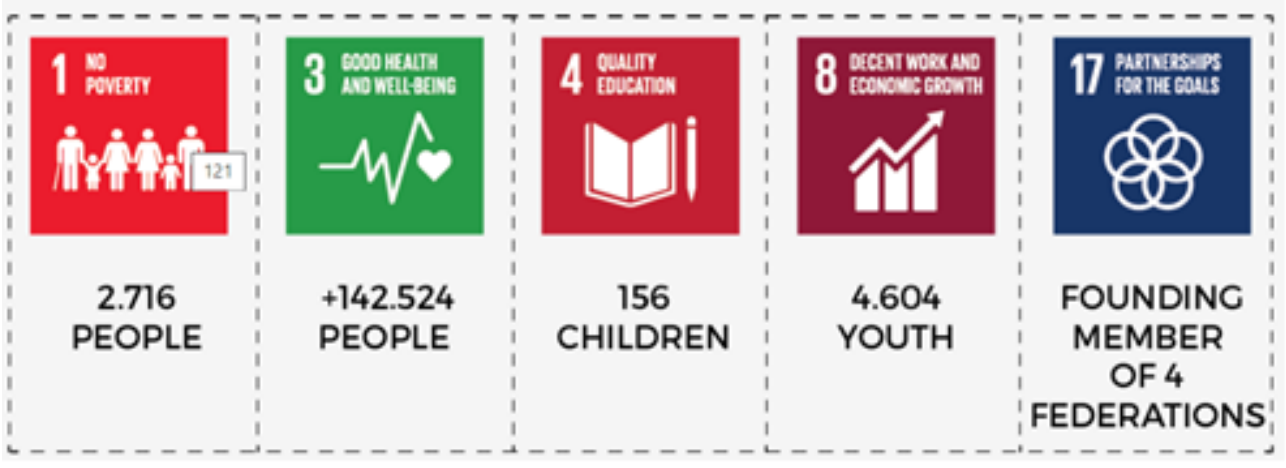

Figure 1. ADV global goals for sustainable development Source: ADV website (2021)

\section{Conclusions}

As we could see the SOP HRD 2007-2013 and the POCU 20142020 reached their main objectives related to the social economy development in Romania, supporting of a large number of beneficiaries from different vulnerable groups. Clearly, as it can be seen, the european funds accomplished their purpose and we can declare the fact that our membership in European Union contributed to the development of social economy in our country.

The local NGOs, such as ASSOC and ADV Romania, have proven their real social impact on human resources development and community investments with huge amounts of money for the social economy domain. We can state the fact that since 2007 until present the investments made in social economy were a truly economic and social advantage for us as people, as members of Europe community. We still have to grow and keep innovate and develop the social economy domain so that we succeed to reduce the poverty from our country and to reduce the number of vulnerable persons and to inform the entire community of our real possibilities 


\section{References}

"Alături de Voi“" Romania (ADV). (n.d.). https://alaturidevoi.ro

ASSOC - Non-Governamental Profesional Asociation of Social Work. (n.d.). https://www.assoc.ro

Ávila, R. C., \& Campos, J. L. M. (2018). The social economy facing emerging economic concepts: Social innovation, social responsibility, collaborative economy, social enterprises and solidary economy [Expanded Abstract]. CIRIEC-Espana Revista de Economia Publica, Social y Cooperativa, 93, 5-50. http://ciriec-revistaeconomia.es/wpcontent/uploads/CIRIEC 9301 expanded abstract.pdf

Carrión, J. J. J., García, J. M. G., \& Arufe, J. E. F. (2020). Social economy and local/rural development. An analysis of synergies. Estudios de Economia Aplicada, 29(1), 189-222. https://doi.org/10.25115/EEA.V29I1.3937

del Carmen Muñoz Medraño, M., Peñalver, A. J. B., \& Santos, J. A. C. (2018). Innovation management and cooperation in the government of social economy entities. Journal of Scientific and Industrial Research, 77(12), 684-687. http://nopr.niscpr.res.in/bitstream/123456789/45488/1/JSIR\%2077\%28 12\%29\%20684-687.pdf

Explanatory Dictionary of the Romanian Language. (n.d.). https://dexonline.ro/

Laurisz, N. (2019). The role of stakeholders in development of social economy organizations in poland: An integrative approach. Administrative Sciences, 9(4), 74. https://doi.org/10.3390/admsci9040074

Romanian Parliament. (2015, July 28). Legea 219 privind economia sociala [LAW no. 219, on the social economy]. Monitorul Oficial, 561. http://www.mmuncii.ro/j33/images/Documente/Legislatie/L2192015.pdf

Lee, E. S., \& Jung, K. (2018). Dynamics of social economy self-organized on social media: following social entrepreneur forum and social economy network on Facebook. Quality and Quantity, 52(2), 635-651. https://doi.org/10.1007/s11135-017-0663-8

Llabinés, N. M., Crespo, P., \& Buil-Fabregà, M. (2018). Social economy companies in the times of crises: Entrepreneurship and survival. Intangible Capital, 14(1), 35-46. https://doi.org/10.3926/ic.1100

Managing Authority for the Human Capital Operational. (2020). Beneficiary guide. https://mfe.gov.ro/programe/autoritati-de-management/am-pocu/

Mandrysz, W. (2020). Community-based social economy - social capital and civic participation in social entrepreneurship and community development. Management Dynamics in the Knowledge Economy, 8(1), 81-93. https://sciendo.com/pdf/10.2478/mdke-2020-0006 
Social Economy as Possible Solution for Social Inclusion and Combating...

Meira, D. (2019). The cooperative economic groups and the problem of the quantification of the social economy entities. REVESCO Revista de Estudios Cooperativos, 131, 103-124. https://doi.org/10.5209/REVE.63562

Ministry of European Funds. (2014). Raportul anual de implementare [Annual implementation report]. https://www.fonduriue.ro/images/files/programe/OLD/POSDRU/rai.posdru.30.06.2015.pdf

Ministry of Finance and Economy. (n.d.). POSDRU 2007-2013. Fonduri UE.ro. https://www.fonduri-ue.ro/posdru-2007

Roldán, F. R., \& Cabrales, Á. L. (2021). Social Economy Values: Human Resource Management and Sustainability. CIRIEC-Espana Revista de Economia Publica, Socialy Cooperativa, 102, 33-59. http://ciriec-revistaeconomia.es/wpcontent/uploads/CIRIEC 10202 Rincon Lopez.pdf

Shin, C. (2016). A conceptual approach to the relationships between the social economy, social welfare, and social innovation. Journal of Science and Technology Policy Management, 7(2). https://doi.org/10.1108/JSTPM-08$\underline{2015-0027}$

Stukalo, N., \& Simakhova, A. (2018). Global parameters of social economy clustering. Problems and Perspectives in Management, 16(1), 3647.https:/doi.org/10.21511/ppm.16(1).2018.04

Tismăneanu, V. (2006). Final raport. https://www.wilsoncenter.org/sites/default/files/media/documents/articl e/RAPORT FINAL CADCR.pdf 